\title{
A Survey of Examination Phobia amongst Students at Secondary School Level
}

\author{
*Muhammad Javed ${ }^{1}$, Imran Khan ${ }^{2}$ \\ ${ }^{1}$ Department of Educational Training, The Islamia University of Bahawalpur, Bahawalnagar Campus, \\ Bahawalnagar, Pakistan \\ 2Department of Management Sciences, The Islamia University of Bahawalpur, Bahawalnagar Campus, \\ Bahawalnagar, Pakistan \\ *mjaved_iub@yahoo.com
}

\begin{abstract}
This paper focuses on exam phobia among students. Exam phobia is an irrational fear that leads to avoidance of the feared situation or object which in turn increases the severity of the phobia. The students having an excessive and unreasonable fear due to exam or the presence or anticipation of a horrible situation causes an anxiety. The sufferer realizes that the fear is irrational; and the avoidance or distress due to the stimuli causes impairment in functioning. Eleven (11) Districts (counties) of the province of the Punjab, Pakistan were taken through convenient sampling. Two public Secondary schools (one male and one female) were selected from each District from urban area randomly. Seventy students (35 students from Boys Secondary school and 35 from Girls Secondary school) of grade 9 from each District were selected randomly. The total sampling was $11 \times 70=770$ students. A questionnaire was developed to collect the data. Data was analyzed by using SPSS version 16.0. The intensity of exam phobia was found. A comparison was also made on gender bases by using t-test. The results showed that the students suffer from exam phobia to some extent. Furthermore the results revealed that the level of exam phobia in male and female students was same. Recommendations have been given on the basis of findings.
\end{abstract}

Key words: Exam Phobia, Fear, Anxiety, Impacts, Treatment

\section{Introduction}

Generally the students who suffer from exam phobia have a strong fear of one or more exam performance situations. They fear that they will perform in a way that is humiliating or embarrassing and that others will judge them negatively. They recognize the reality that this fear is irrational. They experience extreme discomfort and anxiety during exam situations, and seek avoidance whenever possible (Loranger, 1988). Phobia is natural survival mechanism of control due to irrational fears. If someone is attached by the fear, it would provoke extreme response. Common symptoms of phobia include rapid palpitation, nausea, sweating and trembling (Watson \& Friend, 1969). The psychological distress, delusion or obsessional thought are indications of anxiety. It is due to the presence of the particular phobic object or situation (Sarason, 1988).

Muris (2006) mentioned that there are over about 275 types of phobias listed through different sources. The people, having an excessive and unreasonable fear due to the presence or anticipation of a specific object or situation, are indulged in an anxiety. The sufferer realizes that the fear is excessive or unreasonable and escaping from the distress seems complicated. The phobias restricted to highly specific situations such as proximity to particular animals, heights, thunder, eating certain foods, dentistry, the sight of blood, bloodshed or injury, the fear of exposure to specific diseases and examinations create horrifying situations in individuals. Phobias evoke panic, fright and extreme anxiety amongst individuals (Botella, et al., 1998) whereas the fear is irrational and illogical. Botella et al (1998) mentioned five types of specific phobias as animal phobia, natural environment phobia, situational phobias, blood-injection /injury phobia and other phobias which include all phobias excluding the first four categories.

Specific phobias are very common. These phobias are the most common type of anxiety disorder. Scientists believe that phobias can be traced to a combination of genetic predisposition, brain chemistry and other biological, psychological and environmental factors. The impact of a phobia on life depends on how easy it is to avoid the horror object, place or situation. Phobias can disrupt daily routines, work efficiency, diminish self-esteem and twist relationships. Suffering from phobia or anxiety disorder can interfere with many aspects of life. It may cause for embarrassment and frightened. 
Examinations provoke anxiety for some students. They may worry about an exam for days before it is to take place or during exam, when tackling the examination they may experience negative thoughts and unpleasant physical symptoms which prevent them from performing to the best of their ability (Zeidner, 1998) whereas an examination is an evaluation process. It is not a phobia but simply a test to judge students' knowledge and capabilities in their personality. Examination stress puts negative impacts on students' personality. They try to run away from books. They suffer from exam fever which makes failing and contemptuous against exam (Nigel, 1997). Exam means tension, cramming sessions, long breaks to avoid leisure and the tensed situation quite in exam halls. Some students faint out of fear. Generally, exams make the students nervous whether it is written or oral assessment. Students feel it is a significant problem if their work or studies requires participation in group discussions or presentations. Some students fear writing as they are concerned that their hand will shake as they write and performance will be evaluated negatively (Zeidner, 1998).

The present research is highly significant. The results of this study will help to find out the intensity level of exam phobia among students. It will help to compare the anxiety level of male and female students. The results of this study will help the teachers and parents to cope with the problem of exam phobia. This will also help out the school administration to take steps to eliminate the exam phobia among students. The major objectives of the study were bifurcated into following;

- To find out the intensity of exam phobia among Secondary school students.

- To explore the anxiety level, fear, fright, frustration, stress and embarrassment due to exam phobia among students.

- To compare the intensity level among male and female students.

\section{Literature Review}

\section{Clumsy Methodism and Exam Phobia}

Generally laborious and diligent students remain under normal stress whereas weak students remain under heavy stress and phobia. Cheater students keep themselves engrossed in collecting cheating materials and searching new techniques to hide in their body or clothes in examination hall and how to copy tactfully in the presence of invigilators (Kraft, 2010). Intelligent and hardworking students have fear, anger and frustration in their hearts against the teachers having shallow knowledge and cheater students who had never bothered their studies and those who did not attend the classes, but by cheating and influencing on so called educationist, will get better marks than them (Chennai \& Ram, 2002). Rotten Methodism causes exam phobia among students. Basically teaching means to help the students; to make them think, feel or act well in a new or different ways, to instruct them how to do. Ours methodology failed to do this. Consequently, even the intelligent and industrious students fed up and suffer from exam phobia (David, Mel \& Chris, 2002).

Another reason for exam phobia is weak psychology of some parents that prohibit their children to speaking loudly, watching T.V and laughing. Moreover, they impose curfew in their premises and paralyze everybody's tongue, if any child, by mistake, makes a noise or plays with musical toys .They postponed important decisions till exams. They even don't spare the neighbor's servant without beating if he makes sound while grinding in a mortar. That way they deal every one during their children's exam is a mishandling. The children living in such environment gradually lose interest in studies. An unfortunate and abnormal approach among some of the teachers and parents to paint examinations as great trails generates great tension in the minds of children, which leads to nervousness, anxiety, lack of appetite, empty stomach and poor performance in the examinations (Gupta, 2009). One of the major reasons of stress amongst students is the rigid and intolerant behavior of the parents towards their children. As a result, the students become exasperated in reaction which creates anxiety amongst them (Fouzia \& Samina, 2009). The harassing fear of not showing well performance in a forthcoming examination haunts a student which arouses the feelings of nervousness, resulting in profuse sweating, shivering, nausea or dizziness. The best advice is that students should prepare systematically with total dedication and face examinations with confidence without worrying about the results while they are writing the answers (Emmelkamp, Bouman, \& Scholing, 1995). 


\section{Examination Phobia; Anxiety and Stress}

Cassady (2001) found that fear and anxiety affect mind and threat physically or psychologically. According to Jyotsna (2009) it is examination period which is the time of horror and uncertainty for the students. The examinations turn the students into a mass of nerves. Rivera (2010) expressed that teaching has become exam oriented. Every school lays emphasis on the number of successful candidates and the teachers teach only the important points, which might come in the examination. She suggested possible questions and most of the students study selectively which is another factor of anxiety among students. Scott et al. (2006) elaborated that in this game of guesswork, there is no place for knowledge. Half of the students never go through the textbooks. At the start of the session, examinations seem too far away, but as the days pass swiftly and suddenly, they find the examination knocking at their door. They try to get through the examination with the help of all these 'Guide Books', and 'Sure Success' etc. Consequently cramming does not help much and there is no short cut to success. Wilkonson (1990) concluded in his research that the selected study is a cause of anxiety among students.

Stellar (2009) illustrated that the students suffering from exam phobia postpone enjoyment oriented activities. They don't like to go to playground and cancel their picnic schedules too. They remain busy with their books willy-nilly. They go on reading without understanding while sipping a cup of tea or coffee. They go on revising while lying down in their beds. They discuss questions; talk about books and dream about answers with the signs of hopelessness and resentment on their faces. The exam fever reaches the highest point on the night before the examination. The sufferer spends disturbed sleepless night. He gets early in the morning and even the atheists pray for success. Before entering the examination hall, he feels that everything has been washed out of the brain. If someone says," This question is sure to be set." The other student contradicts his speculation. In this reluctance, the student feels disturbance and turns the pages of books in a hasty manner and tries to move his eyes over the answers haphazardly (North, North \& Coble, 1998).

As soon as he takes his seat in the examination hall, he starts to pray to God and revises the questions. If the question paper is difficult, glasses of water are ordered. As he begins to answer the questions, he might feel that most of what he had learnt has evaporated from his memory. Even after the examination is over, the phobia still haunts the student. He tells his friends about the confusion during exams by saying that he could not do justice to some of the questions. He counts his marks daily and thinks that he would get a second class at least. He remains in such type of suspense till the result announcement day arrives. He tries to find his roll number on the list with trembling hands. This movement is very troublesome because failure would invite taunting remarks of the parents, relatives and friends. Unfortunately, if he fails or gets low marks he would be heard saying, 'There is something wrong with the examiner'. Perhaps my answer sheets were replaced with those of weak students (Stellar, 2009). In a nutshell, exam month is considered the cruelest element because it brings a yawn and anxiety for the students and exam phobia, in fact, is a painful experience for each and every student. There are also a few cases in this respect that the disheartened and dejected students suicide due to the fear of exams or failure.

A high level of anxiety may suffer from panic disorder amongst students. The students feel uneasiness, helplessness and severe stress (Watson \& Friend, 1969). Some students become so frightened that they cannot perform well in the examination, even they forget the answers of the questions as they enter in the examination hall (Stellar, 2009). Anxiety disorders are prevalent in the students and can have a destructive influence on students' lives. World Psychiatric Association manual DSM-IV (1995) defined a variety of anxiety disorders including panic disorder, obsessive-compulsive disorder, specific phobia, social phobia and exam phobia. In the context of exposure therapy patients exposed that their anxiety relieves with the passage of time under the process known as habituation (Emmelkamp et al., 1995). Strickland, Hodges, North, and Weghorst (1997) found that a variety of efforts has been made to investigate the causes and remedy to treat such phobias in this way. Fear of flying has also been investigated as has arachnophobia (Carlin, Hoffman, \& Weghorst 1997). Prospective benefits were also found in the application of virtual treatment to exam phobia (North, North \& Cobble 1998) and claustrophobia (Botella et al, 1998). A recent study found that treatment techniques were successful in reducing levels of anxiety and avoidance behavior in acrophobic individuals. To our knowledge, there is only one reported study applying virtual reality to the treatment of social phobia. The work of Muris (2006) suggested that people having a natural tendency to treat such cases will evoke a similar response. 


\section{Overcoming Exam Phobia}

According to Shashank (2008), more than 50 per cent of students suffer from an examination phobia. Almost all the students worry about forgetting in an exam, not being able to recall essential information during solving paper. And these fears become obstacles in their performance, especially during exam days. Another aspect which is a source of anxiety for poor students is that teachers always appreciate only those students who get the highest marks in class. Consequently weak students suffer from exam phobia. The teacher can help the agonizing young minds to remove their fear of exams. Shashank (2008) suggested that the teacher should make the students realize that exams are merely a part of the learning process to explore their skills. The same message should be conveyed to the parents as well. They should appreciate students on their even slightest improvement in performances which will enhance self esteem and amount of hardworking. Appreciation will motivate them. Teachers should help the students find out their own areas of deficiencies. Self assessment helps to locate the area which needs improvement. During exam the students should eat properly and take sound sleeps at night.

\section{What Treatments are Available?}

According to Hanies, Imeson and Meade (2007), Cognitive Behavioral Therapy (CBT) has been found to significantly decrease phobic symptoms by helping the phobia sufferer change his or her way of thinking. Most of the individuals who are treated for phobias and other anxiety disorders feel significant improvement and enjoyment in life. A variety of treatment options are available including Cognitive Behavioral Therapy (CBT), Exposure Therapy, Anxiety Management, Relaxation Techniques, and Medications. Carlin, Hoffman and Weghorst (1997) stated that one or a combination of these may be recommended according to the situation and intensity. No any single treatment is sufficient. If anyone may be suitable for one person perhaps it may not be the best choice for someone else. A professional doctor can suggest a treatment according to the nature of individual for recovery.

Smita (2001) claimed that Behavioral problems in children are common these days. The children throw tantrums or do not listen to their parents, or do not pay adequate attention in studies. They do not eat properly or do not like to take the balanced diet and so on. The teachers and parents should keep an eye on them and if they are highly aggressive then psychological treatments like ignoring, reward management, withdrawal of reinforcements should be sought for it. Smita (2009) expressed that the most important technique to remove or minimize the exam phobia is to study well. Most of the students don't prepare well enough for exams. Selective study is too much dangerous and risky. The guess papers are equally dodgy. The best strategy is to start preparations early keeping in mind a general idea of the course and the major points of all the subjects before starting exams, They should not awake up all night before the exam even if they have lots of studying left to do.

\section{Techniques to Cope with Exam Phobia}

Exams exasperate and the students try to cram everything anxiously. They remain upset while cramming the night before the examination and worry that they cannot retain what they have learnt. They could be suffering from high anxiety due to an inefficient study pattern. They need help. PQRST Model suggested by World Psychiatric Association (1995) is a good revision technique that can be used in this respect to reduce the intensity of exam phobia.

- Preview - skim the material to get an overall preview for clear picture

- Questions - formulate questions which highlight the aims derived from reading

- Read Actively - note the key ideas appropriately

- Summarize - identity the main points using lists, key words and diagrams, etc.

- Test - test by reciting and reviewing the summaries immediately after learning the material and again at later intervals

Muris (2006) stated that the students have the misconception that continuous long hours of study are the secret of high performance levels. It has however been proved scientifically by extensive studies of the human brain that concentration starts to increase after 20 minutes of study, which reaches its zenith after 40-45 minutes and it steadily declines gradually, therefore to increase the time for learning and remembering continuously reduces effectiveness. It is therefore recommended to take regular short 
breaks after about 60 minutes of studies to maximize and sustain the level of memorization and concentration.

Exam time is hectic for students. However, with the support of parents, children can reduce stress and anxiety to some extent. Botella et al., (1998) suggested that parents should be affectionate with their kids. They should encourage the children. They appealed to the parents to let children play for at least an hour a day as the exam approaches. The continuous exercise makes the brain energetic and fresh to function at its optimum. It will also release tension. They also laid stress on parents' role to minimize the amount of stress amongst students who are suffering from exam phobia. Sarason (1988) supported this idea that the students can enhance their examination performance in terms of speed of response and a reduction in perceived examination stress. The psychological distress, delusion or obsessional thought are indication of anxiety. It is due to the presence of the particular phobic object or situation; and the phobic situation should be avoided whenever possible (Sarason, 1988).

\section{How to Revamp the System}

Syncamore and Corey (1990) suggested a few instructions to improve the system which can reduce the exam phobia amongst students:

- Exams would be switched over to semesters instead of annual to relieve pressure.

- Internal and external evaluation should be made comprising written and oral exam.

- A combination of MCQS, short and essay type questions with conceptual and analytical reasoning should be included to test comprehension level and broaden skills not based on memorization.

\section{Method and Procedure}

The intended target population was the students of Secondary school level. Eleven (11) Districts (counties) of the province of the Punjab, Pakistan were taken through convenient sampling. Two public Secondary schools (one male and one female) were selected from each District from urban area randomly. Seventy students (35 students from Boys Secondary school and 35 from Girls Secondary school) of grade 9 from each District were selected randomly. The total sampling was $11 \times 70=770$.

\section{Research Instrument}

After reviewing the related literature, a questionnaire was developed to collect the data from the Secondary school level students from the province of the Punjab. Thirty-five items were carefully included in this rating scale. The questionnaire was personally administered to the sample. The instrument was validated through experts' opinions, followed by a pilot study on a small scale in Feb 2009. In the light of experts' opinions and the pilot study, the items were improved in terms of format/style and contents. The reliability of the instrument was established at 0.83 Cronbach's Alpha which was acceptable to launch the study at large scale (Gay, 2000 \& Hildway, 1999).

\section{Data Analysis}

The data was analyzed by using SPSS version 16.0. Percentage and average response were calculated. The t-test was applied to compare the intensity of exam phobia among male and female students. An overall analysis was done in a single master table for each item which gave a general picture of the intensity of the exam phobia amongst students.

\section{Findings}

All the items included in the questionnaire are analyzed separately. However it was not possible to describe all those results here which expanded in 35 tables. Therefore, the consolidated result of the study is given in two tables only. According to Table No: 1 , the findings of this study show that out of the initial pool of 770 students, $283(36.75 \%)$ students strongly agree that they have 'fear of failing in the exam'. $347(45.06 \%)$ students strongly agree that they feel 'frustration' due to exam. 357 (46.36\%) students also strongly agree that they feel 'unpleasantness' due to exam. Average response of 'fear of failing in exam' 'frustration' 'unpleasantness' and 'anxiety' is calculated 2.19, 2.30, 2.38 and 1.60 respectively which are in between two and three. Related options against two and three are 'agree' and 
'undecided'. Average responses are closer to "agree". So it can be said that the students agree that they feel fear of failing in exams, frustration, unpleasantness and intensity due to exam.

Table: 1: Descriptive analysis: The intensity of Examination Phobia among Students $(\mathrm{N}=770)$

\begin{tabular}{|c|c|c|c|c|c|c|c|}
\hline S N & Variables & $\begin{array}{c}\text { Strongly } \\
\text { Agree (1) }\end{array}$ & $\begin{array}{l}\text { Agree } \\
\text { (1) }\end{array}$ & $\begin{array}{c}\text { Undecided } \\
\text { (3) }\end{array}$ & $\begin{array}{c}\text { Disagree } \\
\text { (4) }\end{array}$ & $\begin{array}{c}\text { Strongly } \\
\text { Disagree (5) }\end{array}$ & $\begin{array}{l}\text { Average } \\
\text { Response }\end{array}$ \\
\hline \multirow[t]{2}{*}{1} & Fear of Failing in & 283 & 266 & 70 & 93 & 58 & \multirow{2}{*}{2.19} \\
\hline & Exams \%age & 36.75 & 34.55 & 9.09 & 12.08 & 7.53 & \\
\hline \multirow[t]{2}{*}{2} & Appetite & 106 & 75 & 130 & 128 & 331 & \multirow[b]{2}{*}{3.65} \\
\hline & \%age & 13.77 & 9.74 & 16.88 & 16.62 & 42.99 & \\
\hline \multirow[t]{2}{*}{3} & Sleeplessness & 180 & 76 & 118 & 115 & 281 & \multirow{2}{*}{3.31} \\
\hline & \%age & 23.38 & 9.87 & 15.32 & 14.94 & 36.49 & \\
\hline \multirow[t]{2}{*}{4} & Terrible Dreams & 56 & 35 & 63 & 95 & 521 & \multirow{2}{*}{4.28} \\
\hline & \%age & 7.27 & 4.55 & 8.18 & 12.34 & 67.66 & \\
\hline \multirow[t]{2}{*}{5} & Sleeping Schedule & 250 & 107 & 86 & 111 & 216 & \multirow{2}{*}{2.92} \\
\hline & \%age & 32.47 & 13.90 & 11.17 & 14.42 & 28.05 & \\
\hline \multirow[t]{2}{*}{6} & Headache & 84 & 88 & 98 & 189 & 311 & \multirow{2}{*}{3.72} \\
\hline & \%age & 10.91 & 11.43 & 12.73 & 24.55 & 40.39 & \\
\hline \multirow[t]{2}{*}{7} & Frustration & 347 & 108 & 116 & 136 & 63 & \multirow{2}{*}{2.30} \\
\hline & \%age & 45.06 & 14.03 & 15.06 & 17.68 & 8.18 & \\
\hline \multirow[t]{2}{*}{8} & Depression & 136 & 65 & 122 & 147 & 300 & \multirow{2}{*}{3.53} \\
\hline & \%age & 17.66 & 8.44 & 15.84 & 19.09 & 38.96 & \\
\hline \multirow[t]{2}{*}{9} & Unpleasant & 357 & 95 & 91 & 119 & 108 & \multirow{2}{*}{2.38} \\
\hline & \%age & 46.36 & 12.34 & 11.82 & 15.45 & 14.03 & \\
\hline \multirow[t]{2}{*}{10} & Anxiety & 549 & 96 & 45 & 40 & 40 & \multirow{2}{*}{1.60} \\
\hline & \%age & 71.30 & 12.47 & 5.84 & 5.19 & 5.19 & \\
\hline \multirow[t]{2}{*}{11} & Performance & 32 & 80 & 128 & 301 & 229 & \multirow[b]{2}{*}{3.80} \\
\hline & \%age & 4.16 & 10.39 & 16.62 & 39.09 & 29.74 & \\
\hline
\end{tabular}

Average response of appetite, headache, depression and performance is calculated 3.65, 3.72, 3.53, and 3.80 respectively which lie in between $3^{\text {rd }}$ and $4^{\text {th }}$ options. Related options against three and four are 'undecided and disagreed'. Average responses are closer to "disagree". So it can be said that the students disagree that exam phobia affects on their appetite, headache, depression and performance. Keeping in view the remaining variables; Average response of 'sleeplessness' and 'sleeping schedule' is 3.31 and 2.92 respectively which show that the students are undecided. Average response of 'terrible dreams' is 4.28 which denotes that the students strongly disagree.

According to data presented in table no 2; average response of female and male students is 2.18 and 2.30 respectively with respect to 'fear of failing in exam' that lies in between the $2^{\text {nd }}$ (agree) and the $3^{\text {rd }}$ (undecided) option. It is closer to 'agree'. It means the female and male students agreed that they feel fear of exam but female students comparatively feel more fear than male students with slight difference of 0.12 . Such type of situation is exiting in almost all variables except a few one. The most mentionable thing is that the average response of 'anxiety' is too low in female and male students as well which is an important impact of exam on students. Average response of female and male students is 1.45 and 1.74 respectively with respect to 'anxiety' due to exam. Female students' average response lies in between the $1^{\text {st }}$ (strongly agree) and the $2^{\text {nd }}$ (agree) option. It is closer to 'strongly agree'. It means that the female students strongly agreed that they feel 'anxiety' due to exam whereas male students' average response lies in between $2^{\text {nd }}$ and $3^{\text {rd }}$ option. It is closer to $3^{\text {rd }}$ option which means they are undecided about their anxiety level.

It can be concluded on the basis of data shown in table No. 2 that there was no significant different in female and male students' views about exam phobia. 


\begin{tabular}{|c|c|c|c|c|c|c|c|c|c|c|c|c|c|c|}
\hline \multirow[b]{2}{*}{ S\# } & \multirow[b]{2}{*}{$\frac{\frac{n}{2}}{\frac{\pi}{\pi}}$} & \multirow[b]{2}{*}{ 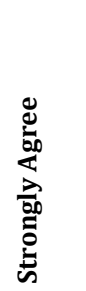 } & \multicolumn{4}{|c|}{$\begin{array}{l}\text { Female Students } \\
\qquad(n=385)\end{array}$} & \multirow[b]{2}{*}{ 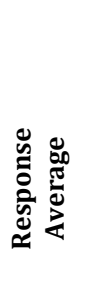 } & \multirow[b]{2}{*}{ 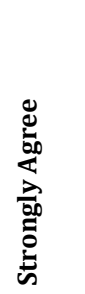 } & \multicolumn{4}{|c|}{$\begin{array}{l}\text { Male Students } \\
\qquad(n=385)\end{array}$} & \multirow[b]{2}{*}{ 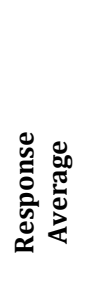 } & \multirow[b]{2}{*}{ 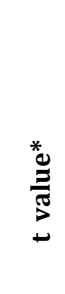 } \\
\hline & & & $\underset{d}{\stackrel{d}{L}}$ & 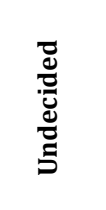 & 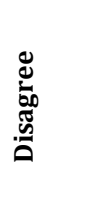 & 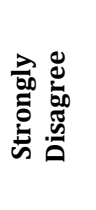 & & & $\underset{d}{\stackrel{D}{L}}$ & 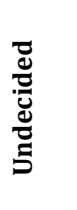 & 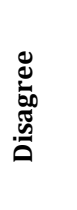 & 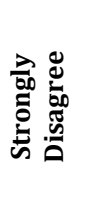 & & \\
\hline \multirow[t]{2}{*}{1} & & & & & & & & & & & & & & \\
\hline & $\begin{array}{l}\text { Fear of } \\
\text { Failing in } \\
\text { Exams } \\
\% \text { age }\end{array}$ & $\begin{array}{c}140 \\
36.36\end{array}$ & $\begin{array}{c}142 \\
36.88\end{array}$ & $\begin{array}{c}42 \\
10.91\end{array}$ & $\begin{array}{c}17 \\
4.42\end{array}$ & $\begin{array}{c}44 \\
11.43\end{array}$ & 2.18 & $\begin{array}{c}143 \\
37.14\end{array}$ & $\begin{array}{c}124 \\
32.21\end{array}$ & $\begin{array}{c}28 \\
7.27\end{array}$ & $\begin{array}{c}41 \\
10.65\end{array}$ & $\begin{array}{c}49 \\
12.73\end{array}$ & 2.30 & 0.995 \\
\hline 2 & $\begin{array}{l}\text { Appetite } \\
\% \text { age }\end{array}$ & $\begin{array}{c}57 \\
14.81\end{array}$ & $\begin{array}{c}45 \\
11.69\end{array}$ & $\begin{array}{c}65 \\
16.88\end{array}$ & $\begin{array}{c}64 \\
16.62\end{array}$ & $\begin{array}{c}154 \\
40.00\end{array}$ & 3.55 & $\begin{array}{c}49 \\
12.73\end{array}$ & $\begin{array}{c}30 \\
7.79\end{array}$ & $\begin{array}{c}65 \\
16.88\end{array}$ & $\begin{array}{c}64 \\
16.62\end{array}$ & $\begin{array}{c}177 \\
45.97\end{array}$ & 3.75 & 0.986 \\
\hline 3 & $\begin{array}{l}\text { Sleeplessn } \\
\text { ess } \\
\% \text { age }\end{array}$ & $\begin{array}{c}99 \\
25.71\end{array}$ & $\begin{array}{c}41 \\
10.65\end{array}$ & $\begin{array}{c}51 \\
13.25\end{array}$ & $\begin{array}{c}57 \\
14.81\end{array}$ & $\begin{array}{c}137 \\
35.58\end{array}$ & 3.24 & $\begin{array}{c}81 \\
21.04\end{array}$ & $\begin{array}{c}35 \\
9.09\end{array}$ & $\begin{array}{c}67 \\
17.40\end{array}$ & $\begin{array}{c}58 \\
15.06\end{array}$ & $\begin{array}{c}144 \\
37.40\end{array}$ & 3.39 & 0.994 \\
\hline 4 & $\begin{array}{l}\text { Terrible } \\
\text { Dreams } \\
\text { \%age }\end{array}$ & $\begin{array}{c}28 \\
7.27\end{array}$ & $\begin{array}{c}24 \\
6.23\end{array}$ & $\begin{array}{c}29 \\
7.53\end{array}$ & $\begin{array}{c}54 \\
14.03\end{array}$ & $\begin{array}{c}250 \\
64.94\end{array}$ & 4.22 & $\begin{array}{c}28 \\
7.27\end{array}$ & $\begin{array}{c}11 \\
2.86\end{array}$ & $\begin{array}{c}34 \\
8.83\end{array}$ & $\begin{array}{c}41 \\
10.65\end{array}$ & $\begin{array}{c}271 \\
70.39\end{array}$ & 4.34 & 0.987 \\
\hline 5 & $\begin{array}{l}\text { Sleeping } \\
\text { Schedule } \\
\text { \%age }\end{array}$ & $\begin{array}{c}133 \\
34.55\end{array}$ & $\begin{array}{c}38 \\
9.87\end{array}$ & $\begin{array}{c}38 \\
9.87\end{array}$ & $\begin{array}{c}59 \\
15.32\end{array}$ & $\begin{array}{c}117 \\
30.39\end{array}$ & 2.97 & $\begin{array}{c}120 \\
31.17\end{array}$ & $\begin{array}{c}66 \\
17.14\end{array}$ & $\begin{array}{c}48 \\
12.47\end{array}$ & $\begin{array}{c}52 \\
13.51\end{array}$ & $\begin{array}{c}99 \\
25.71\end{array}$ & 2.85 & 0.942 \\
\hline 6 & $\begin{array}{l}\text { Headache } \\
\text { \%age }\end{array}$ & $\begin{array}{c}57 \\
14.81\end{array}$ & $\begin{array}{c}38 \\
9.87\end{array}$ & $\begin{array}{c}44 \\
11.43\end{array}$ & $\begin{array}{c}90 \\
23.38\end{array}$ & $\begin{array}{c}156 \\
40.52\end{array}$ & 3.65 & $\begin{array}{c}27 \\
7.01\end{array}$ & $\begin{array}{c}50 \\
12.99\end{array}$ & $\begin{array}{c}54 \\
14.03\end{array}$ & $\begin{array}{c}99 \\
25.71\end{array}$ & $\begin{array}{c}155 \\
40.26\end{array}$ & 3.79 & 0.979 \\
\hline 7 & $\begin{array}{l}\text { Frustration } \\
\text { \%age }\end{array}$ & $\begin{array}{c}187 \\
48.57\end{array}$ & $\begin{array}{c}44 \\
11.43\end{array}$ & $\begin{array}{c}50 \\
12.99\end{array}$ & $\begin{array}{c}73 \\
18.96\end{array}$ & $\begin{array}{c}31 \\
8.05\end{array}$ & 2.26 & $\begin{array}{c}160 \\
41.56\end{array}$ & $\begin{array}{c}64 \\
16.62\end{array}$ & $\begin{array}{c}66 \\
17.14\end{array}$ & $\begin{array}{c}63 \\
16.36\end{array}$ & $\begin{array}{c}32 \\
8.31\end{array}$ & 2.33 & 0.978 \\
\hline 8 & $\begin{array}{l}\text { Depression } \\
\text { \%age }\end{array}$ & $\begin{array}{c}75 \\
19.48\end{array}$ & $\begin{array}{c}29 \\
7.53\end{array}$ & $\begin{array}{c}51 \\
13.25\end{array}$ & $\begin{array}{c}87 \\
22.60\end{array}$ & $\begin{array}{c}143 \\
37.14\end{array}$ & 3.50 & $\begin{array}{c}61 \\
15.84\end{array}$ & $\begin{array}{c}36 \\
9.35\end{array}$ & $\begin{array}{c}71 \\
18.44\end{array}$ & $\begin{array}{c}60 \\
15.58\end{array}$ & $\begin{array}{c}157 \\
40.78\end{array}$ & 3.57 & 0.973 \\
\hline 9 & $\begin{array}{l}\text { Unpleasant } \\
\text { \%age }\end{array}$ & $\begin{array}{c}177 \\
45.97\end{array}$ & $\begin{array}{c}48 \\
12.47\end{array}$ & $\begin{array}{c}47 \\
12.21\end{array}$ & $\begin{array}{c}61 \\
15.84\end{array}$ & $\begin{array}{c}52 \\
13.51\end{array}$ & 2.25 & $\begin{array}{c}180 \\
46.75\end{array}$ & $\begin{array}{c}47 \\
12.21\end{array}$ & $\begin{array}{c}44 \\
11.43\end{array}$ & $\begin{array}{c}58 \\
15.06\end{array}$ & $\begin{array}{c}56 \\
14.55\end{array}$ & 2.38 & 1 \\
\hline 10 & $\begin{array}{l}\text { Anxiety } \\
\text { \%age }\end{array}$ & $\begin{array}{c}295 \\
76.62\end{array}$ & $\begin{array}{c}47 \\
12.21\end{array}$ & $\begin{array}{c}19 \\
9.94\end{array}$ & $\begin{array}{c}9 \\
2.34\end{array}$ & $\begin{array}{c}15 \\
3.90\end{array}$ & 1.45 & $\begin{array}{c}254 \\
65.97\end{array}$ & $\begin{array}{c}49 \\
12.73\end{array}$ & $\begin{array}{c}30 \\
7.79\end{array}$ & $\begin{array}{c}31 \\
8.05\end{array}$ & $\begin{array}{c}21 \\
5.45\end{array}$ & 1.74 & 1 \\
\hline 11 & $\begin{array}{l}\text { Performan } \\
\text { ce } \\
\% \text { age }\end{array}$ & $\begin{array}{c}16 \\
4.16\end{array}$ & $\begin{array}{c}35 \\
9.09\end{array}$ & $\begin{array}{c}59 \\
15.32 \\
\end{array}$ & $\begin{array}{c}167 \\
43.38\end{array}$ & $\begin{array}{c}108 \\
28.05\end{array}$ & 3.82 & $\begin{array}{c}16 \\
4.16\end{array}$ & $\begin{array}{c}45 \\
11.69\end{array}$ & $\begin{array}{c}69 \\
17.92\end{array}$ & $\begin{array}{c}134 \\
34.81\end{array}$ & $\begin{array}{c}121 \\
31.43\end{array}$ & 3.78 & 0.987 \\
\hline
\end{tabular}

Following hypotheses were made to compare 'fear of failing in exams' on gender basis:

1- $H_{0}$ : There is no difference between the 'fear of failing in exams' in male and female students.

2- $\mathrm{H}_{1}$ : There is difference between the 'fear of failing in exams' in male and female students.

In the light of these hypotheses a comparison between the "fear of failing in exams" in male and female students has been made in the Table No. 2. The results revealed no statistical significant difference between the 'fear of failing in exams' in male and female students regarding exam phobia. The $t$-value $(0.995657058)$ for 'fear of failing in exams' was not significant at $\mathrm{p}<0.05$ level of significance, because this calculated t-value lies in between accepted region, therefore the null hypothesis $\left(\mathrm{H}_{0}\right)$ was accepted and it can be concluded that the level of 'fear of failing in exams' in male and female students was same. The average responses for male and female students were 2.30 and 2.18 respectively. Keeping in view the table No.2 the overall results revealed no significant difference between exam phobia (all above stated indicators of exam phobia) in male and female students. All the t-values were not significant at $\mathrm{p}<0.05$ level of significance, because all the calculated t-values lie in between accepted region. Thus, it can be concluded that the level of exam phobia in male and female students was almost same.

\section{Discussion and Conclusion}

As regards the results of this study, it can be said that the exam creates fear among students. It creates the frustration among students and it also increases the rate of sleeplessness. The students are depressed and 
feel unpleasant due to exam. The calculated values of average response show that the fear, sleeplessness, frustration and unpleasantness are the impacts of exam. An anxiety and unpleasantness are more significant on the students' examination phobia. The results demonstrate that the level of exam phobia in male and female students is same. The calculated $t$-values of male and female students in all variables are almost same which illustrate that all the intensity level of exam phobia in male and female students was same.

Exam phobia is an important phenomenon among students. It is natural fact that the activities of the students are affected due to examinations. It is reasonable to conclude from the findings of this study that the exam creates fear and anxiety among students. Students also feel frustration that makes them unpleasant. Previous researches (Carlin, et al., 1997; Botella, et al., 1998) support these findings. The research in this area confirmed that both the male and female students are affected by exam phobia. Consequently the exam phobia put impacts on students' performance.

\section{Recommendations}

It is admitted fact that all the students; male or female, small or young fear of examination. Such type of fear is known as exam phobia. This exam phobia affects students' behavior and performance. It also damages their personality psychologically. Different aspects of their social and emotional development of the personality remain undeveloped and immature due to the fear of exam. In view of above all, it is felt that examinations need reforms from the certain evils connected with present system. Knowledge gained by cramming and tested by theoretical examinations is unsound and superficial. A scientific shape is required to be given to the system of examination.

The students should pay full attention to their studies because the pressure of exams causes of stress, anxiety and frustration among students. It is natural fact that the exam puts strenuous impacts on all students especially on weak students. If the students are fully prepared, the level of intensity can be reduced. The teachers and parents should encourage the students and promote their habits towards learning and studies. They should also try to eliminate the stress and depression amongst students due to the fear of exam. Both the male and female students should prepare themselves fully for exam so that the impacts of exam phobia can be reduced.

\section{References}

Botella, C., Banos, R. M., Perpina, C., Villa, H., Alcaniz, M., \& Rey, A. (1998). Virtual reality treatment of claustrophobia. Behavioral Research and Therapy, 36 (2): 239-246.

Carlin, A., Hoffman, H. G., \& Weghorst, S. (1997). Virtual reality and tactile augmentation in the treatment of spider phobia: a case report. Behavioral Research and Therapy, 35: 153-158.

Cassady, J. C. (2001). The stability of undergraduate students' cognitive test anxiety levels. Practical Assessment, Research and Evaluation, 7 (20): 55-68.

Chennai, B. \& Ram, N. K. (2002). Online edition of India's national newspaper. Retrieved September I4, 2002 from http://www.hinduonnet.com/thehindu/ quest/ 200209 /stories/2002091401710300.htm.

David, P. P., Mel, S., \& Chris, B. (2002). An experiment on public speaking anxiety in response to three different types of virtual audience. Teleoperators and Virtual Environment, 11(1): 68-78.

Emmelkamp, P., Bouman, T., \& Scholing, A. (1995). Anxiety disorder; a practitioner's Guide. New York: Wiley \& Sons.

Fouzia, J., \& Samina, M. (2009). Parenting and children's academic performance: connections and consequences. Journal of Educational Research, 12(1): 170-180.

Gay, L. R. (2005). Educational research competencies for analysis and application (5thed). New York: McMillan Publishing Company.

Gupta, R. (2009). Success in board exams - examination phobia -tips for exams-successful exam preparation. Retrieved May 15, 2010 from http://www.google. com.pk/serach?Hl=en\&q=Roger+Gupta.+\%282009\%29.+Success+in+board+exam++examination+p hobia+-tips+for+exams\&btnG=Search\&aq=f\&aql=\&oq=.

Hanies, J. D., Imeson, \& Meade, T. W. (1987). Phobic anxiety and ischemic heart disease. Br Med J (Clin Res Ed), 295(6593): 297-299. 
Hildway, L. P. (1999). Research in Education. New Delhi: Crescent Publishing Corporation.

Jyotsna, B. (2009). Exam phobia reviews and summaries. Retrieved January 26, 2010 from http://www.shvoong.com/tags/jyotsna-research-exam-phobia.

Kraft, J. (2010). BRIK-landene og tesen om blød balancering. unpublished B. A. analysis, Department of Political Science, University of Aarhus, Denmark (in Danish).

Loranger, A. W. (1988). Personality disorder examination (PDE) manual Yonkers, New York: DV Communications.

Muris, P. (2006). Treatment of specific phobia in children: Are all the components of the phobic response of equal importance? Retrieved January 28, 2010 from http://onlinelibrary.wiley.com/doi/10.1093/clipsy.bpi021/abstract.

Nigel, B. (1997). Clinical report treatment of childhood dental phobia using a modified television visualization technique. Retrieved July 20, 2010 from http://www.goo gle.com.pk/\#hl=en\&source=hp\&biw=1362\&bin=583q=clinical+report+treatment + of + childhood +dental+phobia+using+a+modified+by+Nigel.

North, M. M., North, S. M., \& Coble, I. R. (1998). Virtual reality therapy: an effective treatment for the fear of public speaking. International Journal of Virtual Reality, 3(2): 2-6.

Rivera, K. (2010). Dealing with anxiety before exams. Retrieved December 24, 2010 from http://eng13268.wordpress.com./2010/12/24/dealing-with-anxiety-before-exams/.

Sarason, I. G. (1988). Anxiety, Self-preoccupation, and attention. Anxiety Research, 1: 3-7.

Scott, J. Paykel, E. Morriss, R. Bental, R. Kinderman, P. Johnson, T. \& Hayhurst, H. (2006). Cognitivebehavioral therapy for bipolar disorder. The British Journal of Psychiatry. 188: 488-489.

Shashank, S. (2008). Health and fitness; Retrieved May 10, 2008 and December 0l, 2009 from http://Delhi.quikr.com/f-services-Health-Fitness-0QQ Catldz 653 Fitness.

Smita, P. B. (2001). Multiple perspectives of depression. Paper presented at the 17th National Conference of the Indian Association for Social Psychiatry, Kochi India. 19-21 November 2010.

Smita, P. B. (2009). A comparative study of vocational therapy using structured and unstructured instructions in patients with schizophrenia. Eastern Journal of Psychiatry. 1: 81-83.

Stellar, L. (2009). Introducing the new weight loss program. Retrieved February 02, 2009 from http://forum.healthykey.com/2009/111/introducing-the--called-yometrics.htm lnew-lossweight-program-calledyometric,www.geocities.com/frnxty,and http://www.geocities.com/eoa UK.

Strickland, D., Hodges, L., North, M., \& Weghorst, S. (1997). Overcoming phobias by virtual exposure. Communications of the Association for Computing Machinery (ACM). 40: 34-40.

Syncamore, J. E., \& Corey, A. L. (1990). Reducing test anxiety. Elementary School Guidance \& Counseling, 24: 231-233.

Watson, D., \& Friend, R. (1969). Measurement of social-evaluative anxiety (FNE), Journal of Consulting and Clinical Psychology, 33, 448-457.

Wilkonson, C. M. (1990). Techniques for overcoming test anxiety. Elementary School Guidance

$\&$ Counseling, 24: 234-237.

World Psychiatric Association. (1995). Pocket reference to social phobia. Retrieved May 17, 2010 from http://www.wpanet.org/detail.php?section_id=8\&content_id=133.

Zeidner, M. (1998). Test anxiety: The state of the art. New York: Plenum Press. 